\title{
Семья и образование в идеологическом контексте
}

\author{
Белозерцев Е.П., Гунькина Л.С. \\ Воронежский государственный педагогический университет, \\ Россия, 394043, г. Воронеж, ул. Ленина, 86 \\ E-mail: belozercev_e@mail.ru; 1s_gunkina@mail.ru
}

\begin{abstract}
Аннотация. Духовный кризис современной технократической цивилизации актуализирует необходимость обращения к ценностям семьи и образования. В результате научного анализа авторы приходят к выводу, что отказ от понятия «идеология» привел Россию в секуляризованное общество без идеалов, ценностей, традиций, в котором семья и образование переживают кризис, деформацию, распад. В работе рассмотрена современная трактовка понятия «идеология», взаимосвязь семьи, образования и идеологии, представлен историко-культурный взгляд на семью и образование, методологию педагогического знания, позволяющую семью и образование представить в контексте институциональной идеологии. Цель исследования состоит в обосновании тезиса о необходимости возвращения к феноменологически выявленным изначальным реалиям семьи, которые обнаруживаются в историко-культурных, гносеологических, идеологических и иных предпочтениях.
\end{abstract}

Ключевые слова: семья, образование, институционализация, идеология, институциональная идеология.

Для цитирования: Белозерцев Е.П., Гунькина Л.С. 2020. Семья и образование в идеологическом контексте. Вопросы журналистики, педагогики, языкознания, 39 (4): 566-570. DOI 10.18413/27127451-2020-39-4-566-570

\section{Family and education in an ideological context}

\author{
Evgeny P. Belozertsev, Lyudmila S. Gunkina \\ Voronezh State Pedagogical University, \\ 86 Lenina St, Voronezh, 394043, Russia \\ E-mail: belozercev_e@mail.ru; ls_gunkina@mail.ru
}

\begin{abstract}
The spiritual crisis of the modern technocratic civilization actualizes the need to address the values of the family and education. As a result of scientific analysis, the authors come to the conclusion that the rejection of the concept of "ideology" has brought Russia into a secularized society without ideals, values, traditions, in which the family and education are experiencing a crisis, deformation, decay. The paper examines the modern interpretation of the concept of "ideology", the relationship between family, education and ideology, presents a historical and cultural view of the family and education, the methodology of pedagogical knowledge that allows the family and education to be presented in the context of institutional ideology. The purpose of the study is to substantiate the thesis about the need to return to the phenomenologically identified initial realities of the family, which are found in historical, cultural, epistemological, ideological and other preferences.
\end{abstract}


Key words: family, education, institutionalization, ideology, institutional ideology.

For citation: Belozertsev E.P., Gunkina L.S. 2020. Family and education in an ideological context. Questions of journalism, pedagogy, linguistics, 39 (4): 566-570 (in Russian). DOI 10.18413/2712-74512020-39-4-566-570

\section{Введение}

Вот уже 30 лет как началась модернизация образования в России. Но до сих пор граждане не знают в целостном непротиворечивом изложении цель, задачи, содержание, технологии, ожидаемые результаты задуманной сверху очередной реформы. Не учитывается мнение образовательного сообщества, которое оказывалось в положении исполнителя не всегда понятных и здравых указаний; происходит абсолютизация тех или иных идей, расходящихся с историей нашего государства и культурой нашего народа (ЕГЭ, компетентносный подход, технологии, моделирование, цифровизация, дистанционное образование и др.); сомнительная замена министров, звучат довольно частые, отторгаемые учителями и профессорско-преподавательским составом, выступления с «образовательными» идеями лиц, не имеющих непосредственных отношений к ведомству (Г. Греф, Я. Кузьминов и др.), которые, однако, не получают должной оценки на официальном уровне. Позднее становится известно, что идеи оформляются в законодательные инициативы. Обыватель, он же - учитель и преподаватель, дезориентирован, не может разобраться в потоках противоречивой информации, он устал.

А пока мы все переживаем последствия начального периода строительства новой России, когда слово «идеология» было проклято, отторгнуто и мы оказались в секуляризованном, без мировоззренческих ценностей, обществе. В результате семья, школа, вуз ощутили себя между хаосом (мир без идеологии) и образованием в понимании отдельных людей (меньшинство руководит большинством).

Анализ социальной ситуации в России, отражающейся на состоянии российской семьи и образования, изучение научной литературы, посвященной проблеме сохранения семейных ценностей [Рапацевич 2010; Бордюгов, 2015; Лексин, 2016; Гагаев, Гагаев, 2020], обуславливают необходимость рассмотрения понятия «идеология», раскрытия взаимосвязи семьи, образования и идеологии с точки зрения историко-культурного, гносеологического, идеологического контекста.

\section{Историко-культурные основания взаимосвязи семьи, образования и идеологии}

Под влиянием информационных и медиатехнологий, а также блогосферы сегодня в России идеология, рассматривающая традиционную семью в качестве краеугольного камня современного социума, хотя и с опозданием, но стала предметом интереса исследователей, представителей научного и образовательного сообщества.

Феномен идеологии - неотъемлемая часть культуры, социальная специализация которой «связана с порождением особой картины мира, которая объясняет систему социальных отношений, создавая их вымышленный образ, своего рода социальный фантазм. Возможность сдвигов и изменений внутри этого образа нередко служит основой для идеологических спекуляций и манипуляций сознанием масс» [Щипков, 2018, с. 5].

Имеется большое количество определений данного феномена. Выбор одного из них, как справедливо замечает А.В. Щипков, зависит от идеологических предпочтений выбирающего субъекта. Педагогов прежде всего интересует институциональная идеология, которая «представляет собой не некую мировоззренческую полностью завершенную концепцию "под ключ", а определение общих базовых идеалов, целей и задач. Собственно 
говоря, это условие любой человеческой деятельности, как индивидуальной, так и коллективной» [Щипков, 2018, с. 15].

Александр Владимирович Щипков, являясь убежденным оптимистом, уверен в том, что мировоззренческая и духовная репатриация современного общества России все же состоится. Для этого осмысливается, разрабатывается, вербализируется идеология, ориентированная одновременно к социальному государству, традиционализму и укреплению государственной «вертикали».

Раскрытие феномена «семьи» в историко-педагогическом контексте предполагает обращение к творческому наследию В.В. Розанова, одного из выдающихся отечественных мыслителей и писателей, одно время работавшего учителем мужской гимназии (Елец 1856-1919). Его исследования представляют собой своеобразную энциклопедию духовной и семейной жизни тогдашней России конца XIX - начала XX веков, что облегчает понимание общественной ситуации и в современной России, а потому сохраняют свою значимость и в наше время.

Предвидя современные проблемы, В.В. Розанов в начале ХХ века писал: «Унылый голос о похоронах семьи пропитал все фибры европейского духа» [Розановская энциклопедия, 2008, с. 2072]. Поскольку в христианской семье, по мнению Розанова, из слов Спасителя («и будут два в плоть едину, что Бог сочетал, человек, да не разлучает») выпало главное - плоть, женщина признается причиной греха человеческого, ее обольстительность недоброкачественна, дети осуждены, а «любовь как любование, как привет и ласка», обоих согревающая, - грех [там же]). Остается всего лишь «одно-фамильность, одноимущественность, обще-юридичность» [там же]. Кризис выражается в нравственном вырождении общества, в отрицательном отношении к семье, в отказе от деторождения, в росте «незаконнорожденных» и брошенных детей, в детоубийстве. Между тем «огромное большинство людей жаждут семьи, но, чтобы эта семья навсегда оставалась жаждуемым идеалом, нужно, чтобы она во что бы то ни стало была сохранена в чистоте, целомудрии, в святости своей» [там же].

Определяя фундаментальное место семьи, В.В. Розанов полагает, что в жизни человека все построено на семье и роде: придерживаясь традиционного для русской мысли положения о единстве всего многообразия мира, он считает, что семья находится в единстве с природой, в которой есть пульсация, древнейший в природе ритм, аналогично солнечному: «Мы все дети солнца» ${ }^{1}$.

«Семья есть самая аристократическая форма жизни...» [там же]. У нее своя цель и права, идущие от Бога: супруги и их жизнь, дети и их воспитание. Она - аутокефальное, самовозглавленное явление, первая Богу церковь на Земле со множеством земных функций. Розанов придает особую роль в семье супругу, осуществляющему своим семенем таинство жизнетворения («сочинения мои замешаны на семени»). Жена рассматривалась им как существо воспринимающее, рожающее, пассивно женственное, поддерживающее и воспроизводящее: «Нет выше счастья, как быть матерью... Материнство есть высшая религия» [там же]. Однако Розанов признает сокрытую великую силу женщины - ее «обыкновенный путь состоит в том, что женщина с умом выравнивает кривизны мужа, незаметно ведет его в супружестве к идеалу, к лучшему... в могущественных говорах и ласках ночью». Двое в семье как единая плоть служат тайным основанием любви («любить нужно в семье» [там же]). «Любовь - корень жизни» [там же], в ее признаки включается неизбывная боль за другого и нежность. С ее помощью окормляется святость телесности, порождающего начала семьи. В ее теизме и вечной гармонии, когда муж в жене и жена в муже ощущают начало религиозное и в семейном человеке распознается «образ Божий»,

\footnotetext{
${ }^{1}$ Розановская энциклопедия. 2008. Сост. и гл. ред. А.Н. Николюкин. М., РОССПЭН, 1216 с.
} 
семья предстает как «дом Божий». Это - «непорочная семья», главным условием которой стало очеловечение природы» [там же].

Таким образом, в концепции семьи у Розанова находятся отражение такие животрепещущие для современного общества проблемы, как утверждение абсолютной ценности семьи (метафизическое значение пола и в связи с этим святость брака и деторождения, получающая свое высшее выражение в любви); критика христианского аскетизма, постулата о греховности тела и пола; борьба против ущемления семьи в семейно-брачном законодательстве и в церковных установлениях и др.

В настоящее время традиционная семья переживает глобальный кризис (упадок), сменяется моделью современной семьи, в которой происходит полная смена ценностей. Сторонник «теории кризиса» А.И. Антонов [2009] отмечает, что современная семья зарождается функционально и структурно ослабленной, утратив свои функции в пользу институтов образования, воспитания, религии, работы. Крах целостности брачного, сексуального и в особенности репродуктивного поведения разрушает механизмы семейной стабильности и рождаемости, ведя к тому, что становятся допустимы добрачные отношения, разводы, аборты, внебрачное материнство и др.

Семья воспринимается в обществе как социальный институт в тех случаях, когда образ жизни семьи и ее функционирование соответствуют нашей истории, нашей культуpe, современным общественным потребностям. Семья как социальный институт находится в постоянном изменении, определяемом развитием всего общества и, соответственно, преобразованием общественных потребностей.

С точки зрения А.И. Антонова и В.М. Медкова, [Антонов, Медков, 1996, с. 23] функционирование семьи как социального института определено потребностями социальной системы, заинтересованной в сохранении человечества, общности, нации. Семья не может быть заменена какой-либо другой формой организации. В семье заинтересованы в равной степени и личность, и разного рода общности, и общество в целом. Взаимное согласование интересов предполагает взаимную восприимчивость к потребностям и интересам друг друга. Таким образом, общество должно быть заинтересованно в поддержании института семьи ради собственного развития и существования.

\section{Заключение}

Обобщая сказанное, подчеркнем, что понимание природы семьи и образования есть идеологическое самоопределение размышляющего человека и прояснение его отношения к истории своего государства и культуре своего народа. В историко-педагогическом контексте России семья занимает видное место и объективно является первичной институционализируемой социальной формой естественной связи с обществом и, стало быть, с образованием. Другими словами, семья - неотъемлемая часть институционально организованного образования; одна из ценностей отечественного образования. Наступает момент, когда в силу различных обстоятельств семья обращается в учреждение, предназначенное для общественного воспитания детей раннего возраста (от 2 месяцев до 3 лет - детские ясли) и дошкольного возраста (от 3 лет до 7 лет - детский сад). С этого момента дитя входит в государственную систему, а его семья становится важнейшим элементом и непереоценимой ценностью непрерывного образования Российской Федерации.

Мы понимаем свою задачу так: пора говорить и отстаивать вековечные ценности семьи и образования, защищать родное, бытовое, традиционно воспринимаемые целостно как производное нашей истории и нашей культуры.

Осмеливаемся думать, что «здесь и сейчас», не претендуя на представление мировоззренчески завершенной, непротиворечивой концепции, мы высказались о базовых основах предмета нашего внимания, которые не просто раскрывают контекст семьи и образования, а могут встать среди основных понятий институциональной идеологии, устояв- 
шейся и принимаемой большинством граждан, что будет способствовать сбережению и трансляции ценностей, идеалов и традиций нашего Отечества.

\section{Список литературы}

1. Антонов А.И. 2009. Анализ демографической ситуации и демографической политики в России и мире. В кн.: Демографические исследования. Под ред. А.И. Антонова. М., КДУ: 3-8.

2. Антонов А.И., Медков, В.М. 1996. Социология семьи. М., 23 с.

3. Бордюгов Г.А. 2015. Русский мир в XX начале XXI вв. Берегиня. 777. Сова: общество, политика, экономика, 4 (27): 178-178.

4. Гагаев А.А., Гагаев П.А. 2020. Новая школа: Введение в идеалистическую методологию педагогики. М., А-проджект, 216 с.

5. Лексин В.Н. 2016. Обычная русская семья в условиях трансформации института семьи: Опыт системной диагностики. М., Книжный дом «Либроком», 256 с.

6. Рапацевич Е.С. 2010. Золотая книга педагога. Под ред. А.П. Астахова. Минск, Современная школа, $521 \mathrm{c}$.

7. Щипков А.В. 2018. Вопросы идеологии. М., Абрис/Олма, 320 с.

\section{References}

1. Antonov A.I. 2009. Analiz demograficheskoi situatsii i demograficheskoi poli-tiki v Rossii i mire. [Analysis of the demographic situation and demographic policy in Russia and the world]. In: Demograficheskie issledovaniya. [Population research]. Edited by A. I. Antonov. M., Publ. KDU: 3-8.

2. Antonov, A.I., Medkov, V.M. 1996. Sotsiologiya sem'i. [Sociology of the family]. M., 23 p.

3. Bordyugov G.A. 2015. Russkii mir v XX nachale XXI vv. Bereginya. 777. [Russian world in the XX and early XXI centuries. Bereginya. 777]. Sova: obshchestvo, politika, ekonomika, 4 (27): 178-178.

4. Gagaev A.A., Gagaev P.A. 2020. Novaya shkola: Vvedenie v idealisticheskuyu metodo-logiyu pedagogiki. [The New School: An Introduction to the Idealist Methodology of Pedagogy]. M., Publ. Aprodzhekt, $216 \mathrm{p}$.

5. Leksin V.N. 2016. Obychnaya russkaya sem'ya v usloviyakh transformatsii instituta sem'i: Opyt sistemnoi diagnostiki. [An ordinary Russian family in the context of the transformation of the institution of the family: Experience of system diagnostics]. M., Publ. Book House "Librokom", 256 p.

6. Rapatsevich E.S. 2010. Zolotaya kniga pedagoga. [The teacher's golden book]. Ed. A.P. Astakhova. Minsk, Publ. Sovremennaya shkola, $521 \mathrm{p}$.

7. Shchipkov A.V. 2018. Voprosy ideologii. [Questions of ideology]. M., Publ. Abris/Olma, 320 p.

\section{ИНФОРМАЦИЯ ОБ АВТОРАХ}

Белозерцев Евгений Петрович, доктор педагогических наук, профессор кафедры общей педагогики Воронежского государственного педагогического университета, заслуженный деятель науки РФ, член союза писателей России, г. Воронеж, Россия

Гунькина Людмила Сергеевна, ассистент кафедры социальной педагогики Воронежского государственного педагогического университета, г. Воронеж, Россия

\section{INFORMATION ABOUT THE AUTHORS}

Evgeny P. Belozertsev, Doctor of Pedagogy, Professor of the Department of General Pedagogy, Voronezh State Pedagogical University, Honored Scientist of the Russian Federation, Member of the Russian Writers Union, Voronezh, Russia

Lyudmila S. Gunkina, assistant, Department of Social Pedagogy, Voronezh State Pedagogical University, Voronezh, Russia 